\title{
Environmental influences on germination of utricles and seedling establishment of 'immigrant' forage kochia
}

\author{
MARSHALL R. HAFERKAMP, DAVID C. GANSKOPP, KAY L. MARIETTA, AND BRADFORD W. KNAPP
}

\section{Abstract}

Establishment of forage kochia (Kochia prostrata subsp. virescens) stands from planting utricles has been erratic in the northern Great Basin. This study evaluated the effect of different seedbed environments varied by planting date on germination of utricles and seedling establishment. Utricles harvested in 1986 were planted on tilled seedbeds in late fall, winter, early and late spring 1986-87, and late fall, winter, and early spring 1987-88. Soils are fine-loamy, mixed, mesic, Xerollic Haplargids underlain by coarse gravel at a depth of $1.5 \mathrm{~m}$. Utricles were broadcast at 400 pure live utricles $/ \mathrm{m}^{2}$ in 2 by $2-\mathrm{m}$ plots replicated 5 times. Additionally, nylon bags containing utricles were placed on the soil surface during planting, and on each subsequent planting date, bags of utricles were retrieved for germination trials. Seedling establishment was improved $85 \%(p<0.05)$ when utricles were planted in late fall and winter compared to spring of both 1987 and 1988. Utricles imbibed moisture when incubated in the field from late fall to winter and late fall to early spring 1986-87. When collected in winter 1987, imbibed utricles germinated 7 to 12 days faster $(p<0.05)$ than dry controls, and those collected in early spring germinated 4 to 7 days faster $(p<0.05)$ than controls. Total germination of utricles declined 9 to $20 \%$ with an additional year of storage in the laboratory. Utricles incubated in the field from late fall to winter and late fall to early spring $1987-88$ germinated about 1.5 days faster $(p<0.05)$ than controls when collected in winter and early spring 1988. These findings show why better seedling establishment can be expected from planting freshly harvested forage kochia utricles in late fall and winter before the soil surface begins to dry than in early and late spring in the northern sagebrush (Artemisia) steppe.

Key Words: soil moisture, temperature, sagebrush steppe, forage kochia, utricles, seeds

'Immigrant' forage kochia (Kochia prostrata subsp. virescens) a semievergreen half-shrub of the Chenopodiaceae family has considerable potential as a forage and soil stabilization plant on western rangelands (Keller and Bleak 1974, McArthur et al. 1974, Blauer et al. 1976, Stevens 1983, Stevens and Van Epps 1984, Stevens et al. 1985). Immigrant forage kochia has performed well when planted on several vegetation types including those dominated by pinyon-juniper (Pinus-Juniperus), basin big sagebrush (Artemisia tridentata subsp. tridentata), Wyoming big sagebrush (A. tridentata subsp. wyomingensis), and greasewood-shadscale (Sarcobatus vermiculatus-Atriplex confertifolia) (McArthur et al. 1974, Stevens et al. 1985). The cultivar is adapted to basic, but not acidic or neutral soils, and successful plantings have been established on soils ranging from sandy loam to heavy clay in texture

\footnotetext{
Authors are plant physiologist, USDA-ARS, Fort Keogh Livestock and Range Research Laboratory, Miles City, Mont. 59301; range scientist, USDA-ARS, Squaw Butte Experiment Station, Eastern Oregon Agricultural Research Center, Burns Oregon 97720; former research associate, Eastern Oregon Agricultural Research Center, Burns, Oregon 97720; and statistician, USDA-ARS, Fort Keogh Livestock and Range Research Laboratory, Miles City, Mont. 59301.

The authors acknowledge the assistance of Connie Fisher, Gwen Haferkamp, and Larry Hammond for their assistance in sampling; Diona Austill for assistance with data input; and Linda Duncan for manuscript preparation.

Technical Paper No. J-1445.

Manuscript accepted 16 April 1990.
}

(Stevens et al. 1985).

Two characteristics of this species limit its use on rangelands. These are rapid loss of utricle viability (Balyan 1972, Keller and Bleak 1974, Demin et al. 1977, Waller et al. 1983, Young et al. 1984) and sporadic establishment from direct planting (Keller and Bleak 1974, Lavin and Johnsen 1975, Stevens et al. 1985). Planting during late fall or winter is generally recommended (Balyan 1972, Moghaddam 1978, Stevens et al. 1985). The small utricles $(870 / \mathrm{g})$ contain limited food reserves and must be planted on the soil surface or at shallow depths (Balyan 1972, Young et al. 1981, Stevens and Van Epps 1984, Stevens et al. 1985). This exposes utricles to widely fluctuating seedbed temperatures and soil moisture (Evans and Young 1972, Roundy et al. 1984).

Seeding failures are costly and leave land vulnerable to erosion and invasion by undesirable plants. Identifying relationships between environmental conditions and seedling establishment will provide a basis for designing efficient systems for successful seedings of this species. The objective of this study was to determine the effect of seedbed environment on germination of utricles and seedling establishment for 'Immigrant' forage kochia.

\section{Materials and Methods}

Two lots of utricles of 'Immigrant' forage kochia, harvested in fall 1986, were purchased from a commercial source for studies conducted in the field and laboratory in 1986-87 and 1987-88. Lot 1 was harvested in early fall and air dried before shipment, and lot 2 was harvested about 2 weeks later. Both lots were shipped immediately after lot 2 was harvested. During transit from Ephraim, Utah, both lots imbibed moisture (source of moisture unknown), and upon arrival in Burns, Oregon, lot 1 contained $35.4 \%$ moisture and lot 2 contained $52.2 \%$ moisture. This moisture content was high compared to the $10 \%$ moisture generally contained in lots of utricles received from Ephraim. Utricles of both lots were spread in a thin layer on the laboratory floor in Burns and air dried. After drying, moisture contents were $8.9 \%$ and $8.5 \%$ for lot 1 and lot 2 utricles, respectively. During the experimental period, November 1986 to March 1988, utricles were stored in cloth sacks in the laboratory, and moisture content of utricles varied from 8.9 to $7.7 \%$ for lot 1 and 8.6 to $7.2 \%$ for lot 2 .

The study site was located $2 \mathrm{~km}$ north of Mud Lake in the Harney Basin of southeastern Oregon. Annual precipitation in Harney Basin ranges from $200-300 \mathrm{~mm}$ with $60 \%$ received from October through March (NOAA 1986); summer drought is a distinctive characteristic of the region. Mean annual temperature is $7^{\circ}$ $\mathrm{C}$ with an average daily maximum of $30^{\circ} \mathrm{C}$ in July and an average daily minimum of $-9^{\circ} \mathrm{C}$ in January. Elevation at the site is $1,255 \mathrm{~m}$. Soils are fine-loamy, mixed, mesic, Xerollic Haplargids underlain by coarse gravel at a depth of about $1.5 \mathrm{~m}$. Plots were disced in 1982. Prior to discing, a uniform canopy of greasewood characterized the site with nearly $19 \%$ canopy cover (Romo 1985). Wyoming big sagebrush was the second most abundant shrub, contributing about $7 \%$ canopy cover. Perennial grasses were poorly represented, with western wheatgrass (Pascopyron smithii) the most frequent species. Downy brome (Bromus tectorum) and yellow- 
flower pepperweed (Lepidium perfoliatum) are common throughout the area. Depth to water table is approximately $5 \mathrm{~m}$. During the study, precipitation, snow depth, and soil moisture at the $0-5-\mathrm{cm}$ soil depth were monitored on site. Soil moisture was determined gravimetrically. Temperature records were obtained from the weather station in Burns, Oregon (NOAA 1986).

Both fall 1986 and 1987 seedbeds were prepared by discing or rototilling to a 15-cm depth and smoothed with a rake. Lot 1 and 2 utricles were broadcast onto prepared seedbeds at a rate of 400 pure live utricles $/ \mathrm{m}^{2}$ in each 2 by $2-\mathrm{m}$ plot. Five plots of lot 1 and 2 utricles were planted on each date. First year seedings were made in late fall (4 Dec. 1986), winter (20 Jan. 1987), early spring (25 Feb. 1987), and late spring (31 Mar. 1987). Plant counts were made in May, August, and October 1987. Second year seedings were made in late fall (18 Dec. 1987), winter (29 Jan. 1988), and early spring (8 Mar. 1988). Plant counts were made in May and August 1988. Established plants were counted in 1 by $1-m$ frames located centrally in each plot in May and August 1987 and in the entire 2 by 2-m plot in October 1987 and May and August 1988.

Samples of lot 1 and 2 utricles were also enclosed in nylon bags, made from nylon stockings, and placed on the soil surface in the corner of the 5 seeded plots on each of the 7 planting dates. Nylon bags placed in the field in late fall (1986) were collected in winter (87), early spring (87), late spring (87) and early summer (22 May 1987); bags placed on the soil in winter (1987) were collected in early spring (87), late spring (87) and early summer (87); bags placed in early spring (1987) were collected in late spring (87) and early summer (87); and bags placed in late spring (1987) were collected in early summer (87). A similar sequence of placement and collection occurred in late fall 1987 and winter and early spring 1988. One bag was collected from all 5 replications, and germination activity of the enclosed utricles was compared to dry controls stored in the laboratory. In addition, we studied the effect of air drying of imbibed utricles on subsequent germination of utricles. Samples placed in the field in late fall 1986 and collected in winter 1987 were air dried in the laboratory immediately after collection. Utricles were maintained in an air-dry state until early spring. These dried utricles were germinated with controls and other samples collected from the field in early spring.

Utricles collected from bags in the field were brought to the laboratory and blotted dry. Moisture content of utricles was determined gravimetrically on a sub sample. Immediately after moisture samples were taken, 100 utricles were counted from each replicate and placed on germination blotters (Romo and Haferkamp 1987) moistened with distilled water and contained in a covered Petri dish. Germination trials were begun immediately following sample preparation in controlled environments at $20^{\circ} \mathrm{C}$ with 8 hours light and 16 hours dark for 17 to $\mathbf{4 4}$ days or until germination had ceased. Shorter time periods were required for the trials as afterripening occurred.

No specific size criteria was used in selection of utricles for germination trials. However, when samples were collected from the field in early spring and later, some embryos had begun to uncoil in the nylon bags. When this occurred, care was taken to not select utricles with the embryo uncoiling. Thus, all selections were made from the remaining utricles that may have been less viable. We recognize the limitations in comparing germination data from utricles collected at the later dates, and caution readers of these problems. Thus, comparisons of germination results in late spring and summer are limited to control vs. utricles placed the previous planting date.

Utricles were considered germinated when the embryo was uncoiled, hypocotyl arch was raised and radical was $1 \mathrm{~cm}$ long. Percentage total germination was used to quantify utricle viability, and days to $50 \%$ of final germination was used to quantify germi-
Field plantings in each of the 2 years were arranged in a randomized complete block design with 5 replications. Plantings for year 1 and year 2 were made on adjacent areas. During germination trials, petri dishes were randomly arranged in a germinator, and dishes were rearranged after daily counts were made.

Effect of environment on germination determined by total and days to $50 \%$ germination was analyzed by analysis of variance and means were separated by FLSD. The categorical data analysis procedure (CATMOD) from the SAS program was used to analyze seedling establishment data (SAS Institute Inc. 1988). The model included blocks (5), seed (lot 1 vs. lot 2), planting dates (early fall, winter, carly spring, and late spring), and appropriate interactions. Nonsignificant interactions were deleted from the model. The response variable was $\mathrm{Y}$ for emergence and $\mathrm{N}$ for nonemergence and was weighted by the density factor. The density factor for the $Y$ response was actual count of the plants in a 1 by $1-\mathrm{m}$ plot, and the density factor for the $\mathrm{N}$ response was 400 minus the $\mathrm{Y}$ response. Contrasts of interest were fall and winter vs. early and late spring, fall vs. winter, and early spring vs. late spring. In both analyses, each year and collection date were analyzed separately to eliminate the differences in collection procedure and confounding. Significant differences are noted at $p<0.05$.

\section{Results and Discussion}

'Immigrant' forage kochia seedlings established consistently better from late fall and winter plantings on tilled seedbeds than from early and late spring plantings (Table 1). These 2 planting dates improved establishment regardless of lot or year. Utricles planted in late fall and winter were exposed to an environment of low temperatures and periodic snow cover (Fig. 1). Soil was generally frozen during December, January, and early February. When thawing occurred, the soil surface was moist to muddy (Fig. 2). During

Table 1. Density $\left(\# / \mathrm{m}^{2}\right)$ of forage kochia seedlings emerged on Mud Lake plots near Burns, Oregon.

\begin{tabular}{|c|c|c|c|c|}
\hline \multirow{2}{*}{\multicolumn{2}{|c|}{ Date }} & \multicolumn{3}{|c|}{ Number $/ \mathrm{m}^{2}$} \\
\hline & & \multicolumn{3}{|c|}{ Utricles } \\
\hline Planting & Counting & Lot 1 & Lot 2 & Average \\
\hline Late Fall 86 & 22 May 871 & 22.4 & 28.6 & $25.5 \mathrm{a}^{3}$ \\
\hline Winter 87 & & 3.8 & 6.2 & $5.0 \mathrm{~b}$ \\
\hline Early Spring 87 & & 0.0 & 0.0 & $0.0 \mathrm{c}$ \\
\hline Late Spring 87 & & 0.0 & 0.0 & $0.0 \mathrm{c}$ \\
\hline \\
\hline Late Fall 86 & 7 Aug. $87^{1}$ & 25.2 & 34.6 & $29.9 \mathrm{a}$ \\
\hline Winter 87 & & 7.6 & 11.6 & $9.6 \mathrm{~b}$ \\
\hline Early Spring 87 & & 0.0 & 1.6 & $0.8 \mathrm{c}$ \\
\hline Late Spring 87 & & 0.0 & 0.4 & $0.2 \mathrm{c}$ \\
\hline \multicolumn{2}{|c|}{ 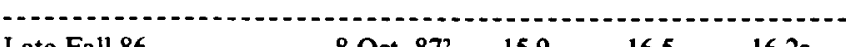 } & 15.9 & 16.5 & $16.2 \mathrm{a}$ \\
\hline Winter 87 & 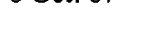 & 3.8 & 7.0 & $5.4 b$ \\
\hline Early Spring 87 & & 0.1 & 1.4 & $0.7 \mathrm{c}$ \\
\hline Late Spring 87 & & 0.4 & 0.6 & $0.5 \mathrm{c}$ \\
\hline \multicolumn{5}{|c|}{ 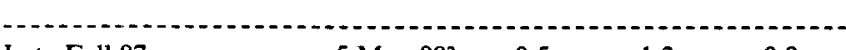 } \\
\hline $\begin{array}{l}\text { Late Fall } 87 \\
\text { Winter } 88\end{array}$ & 5 May $88^{2}$ & $\begin{array}{l}0.5 \\
1.3\end{array}$ & $\begin{array}{l}1.3 \\
1.1\end{array}$ & $\begin{array}{l}0.9 \mathrm{a} \\
1.2 \mathrm{a}\end{array}$ \\
\hline Early Spring 88 & & 0.0 & 0.0 & $0.0 \mathrm{a}$ \\
\hline \multicolumn{5}{|c|}{ 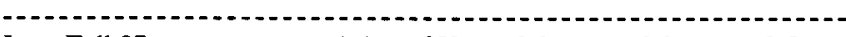 } \\
\hline Winter 88 & & 3.0 & 3.8 & $3.4 \mathrm{a}$ \\
\hline Early Spring 88 & & 0.3 & 0.4 & $0.3 \mathrm{~b}$ \\
\hline
\end{tabular}

I Determinations made in 1 by $1-\mathrm{m}$ frame located centrally in each plot. ${ }^{2}$ Determinations made in each 2 by $2-m$ plot.

${ }^{3}$ Specific comparisons were late fall vs. winter, late fall and winter vs. spring and early spring vs. late spring. Means within collection dates followed by similar letters are not significantly different at $P<0.05$. 


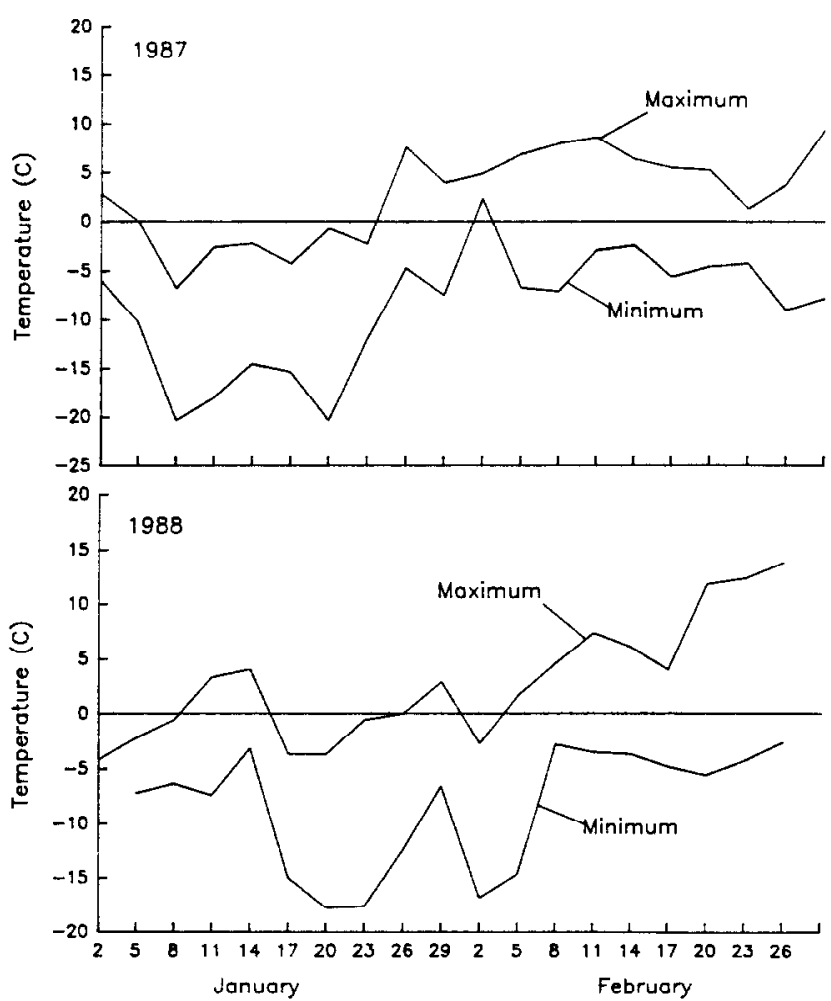

Fig. 1. Temperature profile for Burns, Oregon, during January and February 1987 and 1988.

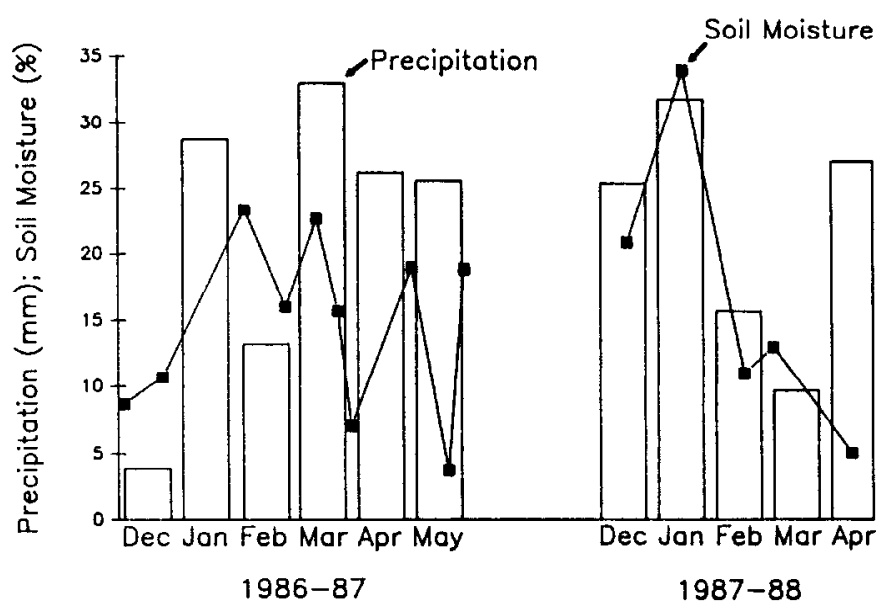

Fig. 2. Precipitation and soil moisture in the 0-5-cm depth for the Mud Lake location near Burns, Oregon, in December-May 1986-87 and 1987-88.

late February and March, temperatures began to rise, and soils began to dry. The soil surface became a mosaic of dry areas and moist depressions. During late March, April, and May, the soil surface was moist only after rains.

Forage kochia utricles responded to cold moist environments of late fall, winter, and early spring. By winter 1987 , utricles placed in late fall 1986 had imbibed 40 to $70 \%$ moisture (data not shown), and rate of germination was 7 to 12 days faster than for controls (Table 2). By early spring, late fall and winter placed utricles contained 35\% moisture (data not shown). The difference in moisture content between winter and early spring suggests moisture content of utricles was dependent upon current soil moisture content at collection time. Rate of germination of the late fall and winter placed utricles was increased 4 to 6 days compared to controls (Table 2 ). The enhanced germination by late fall placed
Table 2. Days to $50 \%$ germination and total \% germination for forage kocia fruits placed in the field in nylon bags at the Mud Lake site near Burns, Oregon, and collected on selected dates.

\begin{tabular}{|c|c|c|c|c|c|c|}
\hline \multicolumn{2}{|c|}{ Date } & \multirow{2}{*}{\multicolumn{3}{|c|}{$\begin{array}{c}\text { Days to } 50 \% \\
\text { Utricles } \\
\end{array}$}} & \multirow{2}{*}{\multicolumn{2}{|c|}{$\begin{array}{c}\begin{array}{c}\text { Total } \% \\
\text { Germination }\end{array} \\
\text { Utricles } \\
\end{array}$}} \\
\hline \multirow[b]{2}{*}{ Planting } & \multirow[b]{2}{*}{ Collection } & & & & & \\
\hline & & Lot 1 & Lot 2 & Average & Lot 1 & Lot 2 \\
\hline Control & Winter 87 & $15.2_{\mathrm{a}}^{\mathrm{A}_{1}}$ & $9.2_{\mathrm{a}}^{\mathrm{B}}$ & & $46.8_{a}^{A}$ & $63.8^{B}$ \\
\hline Late Fall 86 & & $3.0_{\mathrm{b}}^{\mathrm{A}}$ & $2.0 \mathrm{~A}$ & & $45.2_{\mathrm{a}}^{\mathrm{A}}$ & $79.0_{\mathrm{b}}^{\mathrm{B}}$ \\
\hline Control & $\begin{array}{l}\text { Early } \\
\text { Spring } 87\end{array}$ & $9.4_{\mathrm{a}}^{\mathrm{A}}$ & $6.0^{\mathrm{B}}$ & & $57.6_{\mathrm{b}}^{\mathrm{A}}$ & $79.6^{\mathrm{B}}$ \\
\hline Late Fall 86 & & $1.6_{c}^{\mathrm{A}}$ & $2.0 \mathrm{~A}$ & & $69.2_{\mathrm{a}}^{\mathrm{A}}$ & $54.2_{\mathrm{c}}^{\mathrm{B}}$ \\
\hline $\begin{array}{l}\text { Dried } \\
\text { Late Fall } 86\end{array}$ & & $2.8 \mathrm{~A}$ & $2.0 \mathrm{~A}$ & & $46.2_{\mathrm{c}}^{\mathrm{A}}$ & $66.8_{\mathrm{b}}^{\mathrm{B}}$ \\
\hline Winter 87 & & $3.4_{\mathrm{b}}^{\mathrm{A}}$ & $2.0 \mathrm{~b}_{\mathrm{b}}^{\mathrm{B}}$ & & $51.6_{\mathrm{bc}}^{\mathrm{A}}$ & $75.4_{\mathrm{a}}^{\mathrm{B}}$ \\
\hline Control & $\begin{array}{l}\text { Late } \\
\text { Spring } 87\end{array}$ & 6.2 & 4.4 & $5.3 \mathrm{a}$ & $60.0_{\mathrm{a}}^{\mathrm{A}}$ & $81.8_{\mathrm{a}}^{\mathrm{B}}$ \\
\hline $\begin{array}{l}\text { Early } \\
\text { Spring } 87\end{array}$ & & 2.4 & 1.8 & $2.1_{b}$ & $53.4_{\mathrm{a}}^{\mathrm{A}}$ & $32.8_{b}^{B}$ \\
\hline Average & & $4.3^{A}$ & $3.1^{\mathrm{B}}$ & & & \\
\hline Control & Summer 87 & 3.4 & 2.6 & & $52.8_{\mathrm{a}}^{\mathrm{A}}$ & $73.4_{\mathrm{a}}^{\mathrm{B}}$ \\
\hline $\begin{array}{l}\text { Late } \\
\text { Spring } 87\end{array}$ & & 3.4 & 1.8 & & $35.2 \mathrm{~A}$ & $19.8_{\mathrm{b}}^{\mathrm{B}}$ \\
\hline Average & & $3.4^{\mathrm{A}}$ & $2.2^{\mathrm{B}}$ & & & \\
\hline Control & Winter 88 & 4.8 & 4.0 & $4.4 \mathrm{a}$ & $25.2_{\mathrm{a}}^{\mathrm{A}}$ & $54.8_{\mathrm{a}}^{\mathrm{B}}$ \\
\hline Late Fall 87 & & 2.6 & 2.4 & $2.5^{\mathrm{b}}$ & $10.4 \mathrm{~A}$ & $28.0_{\mathrm{b}}^{\mathrm{B}}$ \\
\hline Control & $\begin{array}{l}\text { Early } \\
\text { Spring } 88\end{array}$ & 4.4 & 3.8 & $4.1 \mathrm{a}$ & $23.0_{\mathrm{a}}^{\mathrm{A}}$ & $55.0_{\mathrm{a}}^{\mathrm{B}}$ \\
\hline Late Fall 87 & & 2.6 & 2.2 & $2.4_{b}$ & $7.8_{\mathrm{b}}^{\mathrm{A}}$ & $7.8_{\mathrm{c}}^{\mathrm{A}}$ \\
\hline Winter 88 & & 2.8 & 2.0 & $2.4 b$ & $12.2_{\mathrm{ab}}^{\mathrm{A}}$ & $24.4_{\mathrm{b}}^{\mathrm{B}}$ \\
\hline Average & & $3.3^{\mathrm{A}}$ & $2.7^{\mathrm{B}}$ & & & \\
\hline
\end{tabular}

'Lot means within planting and collection dates followed by similar superscripts are not significantly different at $P<0.05$. Planting date means within collection date and utricle lot followed by similar subscripts are not significantly different at $P<0.05$.

utricles collected in winter was maintained after utricles were air dried and stored in the laboratory. By early spring, lot 1 utricles incubated in the field from late fall to early spring germinated slightly more rapidly than utricles incubated in the field from late fall to winter and stored dry from winter to early spring (Table 2). Germination rates were similar for lot 2 utricles whether dried in the laboratory or incubated in the field.

Total germination of lot 2 utricles at the winter collection date was increased by incubation on soil in late fall, but total germination of lot 1 utricles was not affected (Table 2). The increase in total germination of lot 2 utricles may have resulted from an acceleration of afterripening occurring in the field environment. Several authors report utricles of forage kochia are dormant immediately after harvest and require 4 to 4.5 months for afterripening and removal of dormancy (Balyan 1972, Waller et al. 1983).

By the early spring 1987 collection date, total germination was 
development could be extended. This may occur in areas with a high proportion of spring rains of sufficient duration to allow surface soil to remain moist for several days, or with utilization of soil moisture conservation techniques, such as furrows or mulching.

\section{Literature Cited}

Balyan, G.A. 1972. Prostrate summer cypress and its culture in Kirghizia. (Translated from Russian) 261 p. Al Ahram Cen. Sci. Transl., Nat. Tech. Infor. Ser. TT77-59026.

Bewley, J.D., and M. Black. 1985. Seeds physiology of development and germination. Plenum Press, New York.

Blauer, A.C., A.P. Plummer, E.D. McArthur, R. Stevens, and B.C. Giunta. 1976. Characteristics and hybridization of important intermountain shrubs. II. Chenopod family. USDA-Forest Serv. Res. Pap. INT-177.

Bleak, A.T. 1959. Germinative characteristics of grass seed under snow. J. Range Manage. 12:298-302.

Demin, Y., A. Marikin, and V. Smagin. 1977. The storage of Kochia prostrata seeds. Herbage Abstr. 47:628.

Evans, R.A., and J.A. Young. 1972. Germination and establishment of Salsola in relation to seedbed environment. II. Seed distribution, germination and seedling growth of Salsola and microenvironmental monitoring of the seedbed. Agron. J. 64:219-224.

Keller, W., and A.T. Bleak. 1974. Kochia prostrata: a shrub for western ranges? Utah Sci. 34:24-25.

Lavin, F., and T.N. Johnsen, Jr. 1975. Forage shrub adaptation trials at three pinyon-juniper sites. USDA-ARS, ARS W-29.

Mayer, A.M., and A. Poljakoff-Mayber. 1975. The germination of seeds. Second edition. Pergamon Press Inc., New York.

McArthur, E.D., B.C. Giunta, and A.P. Plummer. 1974. Shrubs for restoration of depleted ranges and disturbed areas. Utah Sci. 34:28-33.

Moghaddam, M.R. 1978. Kochia prostrata-a plant material for range improvement in arid and semiarid regions. Rangeman's Journal 15:153-154.

National Oceanic and Atmospheric Administration. 1986-1988. Climatological data annual summary, Oregon. 92-94:(13).

Romo, J.R. 1985. Water relations in Artemisia-tridentata subsp. wyomingensis, Sarcabotus vermiculatus, and Kochia prostrata. Ph.D. Thesis, Oregon State Univ., Microfilms. Ann Arbor, Mich. (Diss. Abstr. 46:384).
Romo, J.R., and M.R. Haferkamp. 1987. Forage kochia germination response to temperature, water stress, and specific ions. Agron. J. 79:27-30.

Roundy, B.A., R.A. Evans, and J.A. Young. 1984. Surface soil and seedbed ecology in salt-desert plant communities, p. 66-74. In: A.R. Tiedemann, E.D. McArthur, H.C. Stutz, R. Stevens and K.L. Johnsen (compilers). Proc.-symposium on the biology of Atriplex and related chenopods; 2-6 May 1983; Provo, Utah; USDA Forest Serv. Gen. Tech. Rep. INT-172.

SAS, Institute Inc. 1988. SAS/STAT user's guide, release 6.03 edition. Cary, N.C.

Stevens, R. 1983. Species adapted for seeding mountain brush, big, black and low sagebrush and pinyon-juniper communities. p. 78-82. In: S.B. Monsen and N. Shaw (compilers). Managing intermountain rangelandsimprovement of range and wildlife habitat; Proc. Symp.: 15-17 Sept. 1981, Twin Falls, Idaho, and 1982 June 22-24, Elko, Nev.; USDA-Forest Serv. Gen. Tech. Rep. INT-157.

Stevens, R., K.R. Jorgensen, E.D. McArthur, and J.W. Davis. 1985. 'Immigrant' forage kochia. Rangelands 7:22-23.

Stevens, R. 1983. Species adapted for seeding mountain brush, big, black and low sagebrush and pinyon-juniper communities, p. 78-82. In: S.B. Monsen and N. Shaw (compilers). Managing intermountain rangelandsimprovement of range and wildlife habitat; Proc. Symp.; 15-17 Sept. 1981, Twin Falls, Idaho, and 22-24 June 1982, Elko, Nev.; USDA-Forest Serv. Gen. Tech. Rep. INT-157.

Waller, S.S., C.M. Britton, D.K. Schmidt, J. Stubbendieck, and F.A. Sneva. 1983. Germination characteristics of two varieties of Kochia prostrata (L.) Schrad. J. Range Manage. 36:242-245.

Wilson, A.M. 1973. Responses of crested wheatgrass seeds to environment. J. Range Manage. 26:43-46.

Young, J.A., R.A. Evans, B.A. Roundy, and G.S. Cluff. 1984. Ecology of seed germination in representative Chenopodiaceae, p. 159-165. In: A.R. Tiedemann, E.D. McArthur, H.C. Stutz, R. Stevens, and K.L. Johnson (compilers). Proc.-symposium on the biology of Atriplex and related chenopods; 2-6 May 1983, Provo, Utah; USDA Forest Serv. Gen. Tech. Rep. INT-172.

Young, J.A., R.A. Evans, R. Stevens, and R.L. Everett. 1981. Germination of Kochia prostrata seed. Agron. J. 73:957-961.

Should we Dial a-Satellite to find your new address? Just sending us your new address along with an old label will probably get your journai to you faster. (No criticism of satellites intended!) Send the information to Society for Range Management, 1839 York Street, Denver, Colorado 80206. 